DOI: $10.2478 / \mathrm{v} 10025-011-0009-1$

JOURNAL OF WATER

AND LAND DEVELOPMENT

J. Water Land Dev. No. 14, 2010: 101-113

\title{
Costs of the construction and operation of irrigation systems in recreation and sports areas
}

\author{
Radosław GULCZYŃSKI, Czesław PRZYBYŁA
}

Department of Land Improvement, Environmental Development and Geodesy, University of Life Sciences in Poznań

\begin{abstract}
The paper discusses the problems of investment costs of irrigation systems in recreation and sports objects and the costs of maintenance and operation of these systems. For this purpose, source materials referring to six objects realized in the years 2006-2007 in Konin district were analysed. Particular consideration was devoted to the irrigation system, water intake and costs of the construction and operation of the irrigation system in various operation conditions. Furthermore, cost analysis included the maintenance and operation of particular objects. In effect of these studies, the investment unit costs per square meter of area were calculated.
\end{abstract}

Key words: irrigation system, sprinkler, drip-irrigation line, water intake

\section{INTRODUCTION}

Wielkopolska region (acc. to DRUPKA, 1976) is classified to zone I, i.e. to a class of areas with the highest degree of purposeful localization of irrigation systems. The reason is not only in unfavourable relation between potential evapotranspiration and precipitations (from April to September) amounting $>1.6$, but also in soil conditions (DRUPKA, 1976). Soils in Wielkopolska are characterized by a small retention which leads to water deficit in the period of plant growth (PRZYBYŁA and KOZACZYK, 2004). These soil properties require effective irrigation. It is assumed that the best irrigation conditions are attained in medium and medium-light soils. Heavy soils, thanks to a high water capacity, do not require irrigation, while light soils show too small retention capacity and hence do not retain enough water (BARTOSIEWICZ, 1977). Water shortage in recreation and sports areas localised within urban terrain is also associated with an excessive soil compactness and not permeable hardened spots that impede permeation of rain water.

The objective of this work was to estimate the cost connected with the installation and operation of irrigation systems in recreation and sports areas localised in towns. The studies referred also to water sources and to economic variants of the irrigation system operation. 


\section{MATERIAL AND METHODS}

The presented paper contains data on the construction and operation of irrigation systems for six objects localised in the area of Konin district in the years 2006-2007. Detailed characteristics of the objects are shown in Table 1. Because of different purposes for which the described objects are destined, the areas covered by irrigation systems are also different. The areas were divided into grassy areas irrigated by a system emerging from the ground and areas with planted vegetation irrigated by drip-irrigation system. In recreation and relaxation areas (objects I, III, VI), the greatest influence is exerted by the communication system with elements of small architecture, which divide the area utilised by landscape architecture. Another „barrier” is the existing vegetation which has to be included into the irrigation system. Most frequently, a drip-irrigation line is utilised for this purpose and it is spread under a layer of agrofibre and bedding material. There are three spray openings with an output of $2.2 \mathrm{dm}^{3} \cdot \mathrm{h}^{-1}$ along one metre of the drip-irrigation line. Thanks to pressure compensation, it is possible to obtain a uniform water output along the whole drip-irrigation line. Such solution is optimal for the vegetation from both the biological and the economic points of view. An adequate water dose is supplied directly under plants which makes water easily available and maximally utilised by the plants. Furthermore, the presence of agrofibre and the bedding material contribute to a longer maintenance of substrate moisture. In case of objects II, IV and V, i.e. those destined for sports purposes, the area covered by the irrigation system is not so much complicated.

This elaboration is based on investments which have the character of a competitive tendering. Therefore, for the needs of a public tender, it is necessary to prepare an investor's cost calculation based on standardized work time. These standards are contained in the so called "Catalogues of standardized work time" which are available in paper or electronic forms. Cost calculations were carried out with the calculation programme. Cost of the construction of irrigation system was calculated based on the list of works to be done, where the units (before measurement) are given from the project documentation and technical specification. The labour value is determined from unit prices of work calculated by the contractor or from commonly available catalogues of standardized work time. Works carried out within the range of irrigation systems are mainly grouped in:

1) Catalogues of the labour costs (KNR):

- KNR 2-01 (constructions and labour of earth structures),

- KNR 4-01 (building and overhaul works),

- KNR 2-18 (external water and sewage system networks),

- KNR 4-03 (overhaul work of electric installations).

2) Costs of standard material expenditures (KNNR) such as:

- KNNR 5 (wiring system and external network installations). 


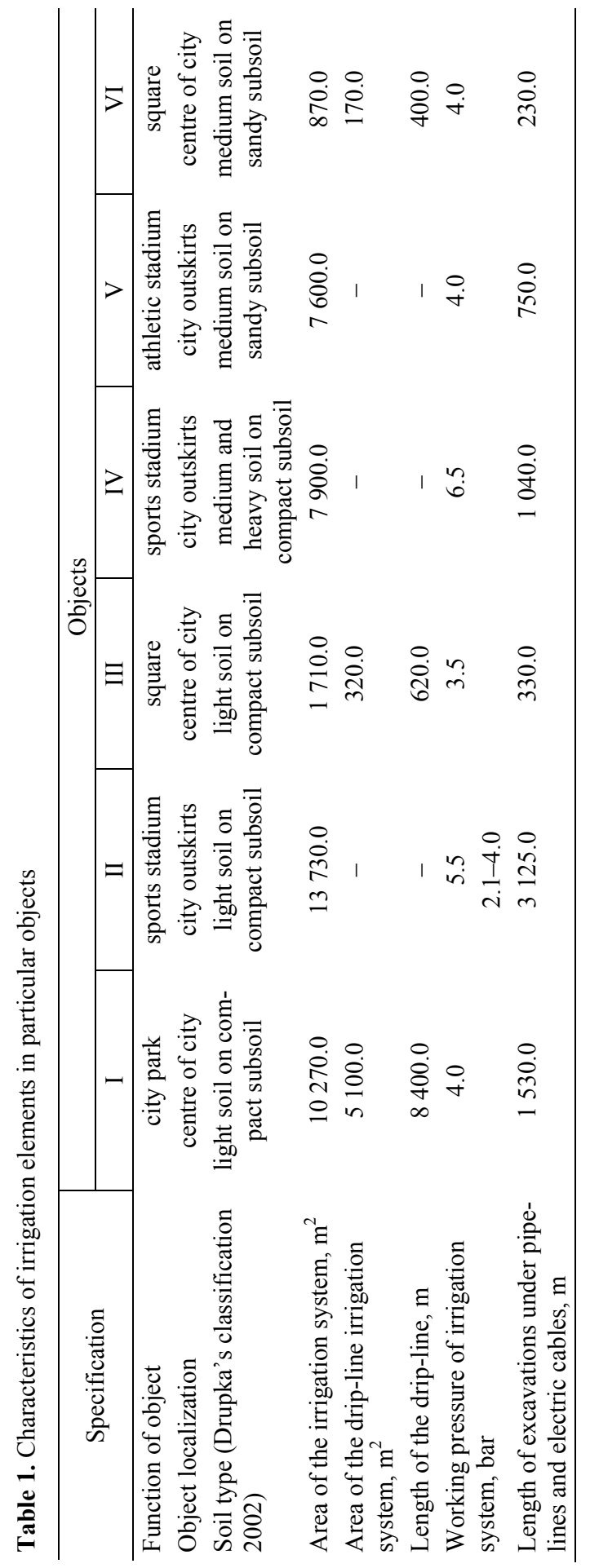


When the range of works was different from those in the standard catalogues, then own calculation (KW) was carried out based on individual work estimation. KW requires the determination of standard time of the performed works. i.e. the number of measurements made per work hour. In case of earth works, one must consider an additional factor - the soil category (I-IV), where I denotes light soil, and IV - heavy soil. Own calculations were qualified in an analogical way - distribution of dripping line on the surface with different inclinations (I-IV), where I denotes flat area and IV - terrain with escarp inclination $>45^{\circ}$.

3) KNRs, KNNRs and KW constitute cost calculation items which were additionally defined by supplemental factors:

- detailed analysis of work to be done (quantity survey),

- outlays,

- average unit costs:

a) labour (R) expressed in man-hours,

b) materials $(\mathrm{M})$ expressed in units,

c) equipment (S) expressed in machine-hours,

For better understanding, the particular items were divided into groups:

- earth works,

- irrigation installations - pipelines,

- wiring systems - conductors and electrical equipment,

- technological equipment of inspection shafts,

- start up of the irrigation system.

The analysis of effectiveness costs was carried out based on expression:

$$
E_{b}=\left(I s+K_{b}\right): V \rightarrow \text { minimum }
$$

where:

$E_{b}$ - seasonal unit cost, $\mathrm{PLN} \cdot \mathrm{m}^{-2}$ or PLN $\cdot \mathrm{m}^{-3}$;

$I$ - construction of irrigation system;

$s$ - rate of depreciation, $\%$;

$K_{b}$ - operation costs, PLN;

$V$ - irrigated area, $\mathrm{m}^{2} /$ sprinkling of water, $\mathrm{m}^{3}$.

Three types of years: dry year, average, and wet year were distinguished based on the sum of atmospheric precipitation. It was assumed that in a dry year 100 irrigation days are needed per the vegetation season, in an average year - 75 and in a wet year - 50 irrigation days.

For the three types of years, the following costs were calculated: operation costs per $1 \mathrm{~m}^{2}$ of area, costs of $1 \mathrm{~m}^{3}$ of water used for irrigation and unit costs of the construction and operation of installed irrigation system. 


\section{RESULTS}

An essential component of costs is the area development and the equipment of the area with water and electric service lines. In objects II and IV, deep wells were made while in object I pipelines to water supply system were provided. All objects were equipped with electric power lines located in inspection shafts (Tab. 2). The remaining costs of the irrigation system construction and operation are presented in Table 3 .

Table 2. Characteristics particular objects and costs of their provision with water

\begin{tabular}{|c|c|c|c|c|c|c|}
\hline Specification & I & II & III & IV & $\mathrm{V}$ & VI \\
\hline $\begin{array}{l}\text { Characteristics of } \\
\text { water intake }\end{array}$ & $\begin{array}{l}\text { well ø } 1.5 \mathrm{~m} \text {, } \\
\text { depth } 4 \mathrm{~m} \text {, con- } \\
\text { nected with lake } \\
+ \text { weir }\end{array}$ & $\begin{array}{c}\text { well } 80 \mathrm{~m} \\
\text { deep }\end{array}$ & $\begin{array}{c}\text { water } \\
\text { supply } \\
\text { network }\end{array}$ & $\begin{array}{c}\text { well } 95 \mathrm{~m} \\
\text { deep }\end{array}$ & $\begin{array}{c}\text { water } \\
\text { supply } \\
\text { network }\end{array}$ & $\begin{array}{c}\text { water } \\
\text { supply } \\
\text { network }\end{array}$ \\
\hline $\begin{array}{l}\text { Water intake con- } \\
\text { struction cost, PLN }\end{array}$ & $15,000.00$ & $14,400.00$ & 500.00 & $17,100.00$ & 500.00 & 500.00 \\
\hline $\begin{array}{l}\text { Purchase and instal- } \\
\text { lation cost of mate- } \\
\text { rials, PLN }\end{array}$ & $16,125.00$ & $16,650.00$ & $1,000.00$ & $11,613.06$ & $1,500.00$ & $1,000.00$ \\
\hline
\end{tabular}

Apart from the number and method of the distribution of irrigation points, attention should be paid in irrigation systems to the proper selection of nozzles which permit rational way of water discharge by sprinklers. Adequate selection of nozzles can balance the sprinklers discharge in a full range of operation $\left(360^{\circ}\right)$ using a sprinkler with a working angle of e.g. $180^{\circ}$. In practice, the applied nozzles are often not differentiated which causes a non-uniform distribution of water over the irrigated area. A control mechanism regulates water discharge and the irrigation frequency. Standard options of the control mechanism include the work-time setting and the irrigation frequency, but water budget can also be regulated. This is often expressed in percentages, where the value of $100 \%$ corresponds to the programmed irrigation time; when the value is lowered by $50 \%$ the irrigation time is shortened by half. Thanks to this property, one can easily and quickly control water discharge by adjusting it to atmospheric conditions. These installations permit that the operation is significantly simpler and also less expensive. A rain sensor can be connected to the control mechanism, which automatically switches off the irrigation system, when water in the rain water reservoir reaches a determined level. The system returns to its normal operation after water evaporation. One should notice that water evaporates from the reservoir in a very similar way as it does from the soil surface. This sensor is localised in an open site to enable rain water collection in a natural way. 


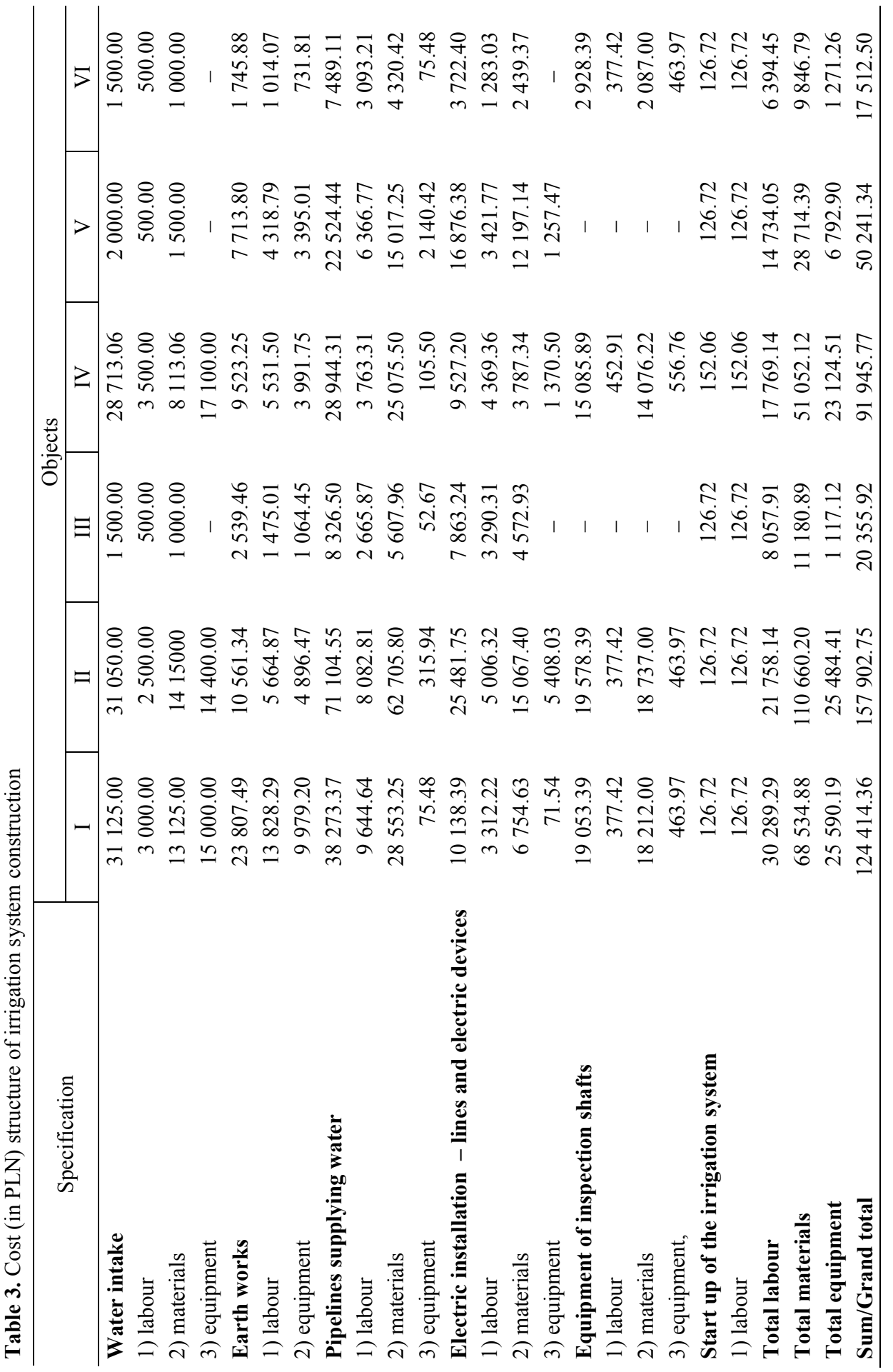


The construction of irrigation systems is counted among fixed assets, therefore, it is subject to depreciation (Tab. 4). Based on annual depreciation rate of $20 \%$, a 5 -year depreciation charge period was determined. During this period, the base of depreciation calculation must be increased to the level of the new investment value in case of a breakdown of any element of the system. Another process of investment accounting is followed depending on the investor type. Budgetary units have no costs, therefore, investments connected with the construction of irrigation systems are accounted only in the form of depreciation. Enterprises account such investment types either in the form of costs or depreciations.

Table 4. Depreciation of irrigation system elements

\begin{tabular}{c|c|c|c}
\hline Objects & $\begin{array}{c}\text { Base of depreciation } \\
\text { PLN }\end{array}$ & $\begin{array}{c}\text { Rate of depreciation } \\
\%\end{array}$ & $\begin{array}{c}\text { Annual depreciation of installation } \\
\text { PLN }\end{array}$ \\
\hline I & 124414.36 & 20 & 24882.87 \\
II & 157902.75 & 20 & 31580.55 \\
III & 20355.92 & 20 & 4071.18 \\
IV & 91945.77 & 20 & 18389.15 \\
V & 34241.34 & 20 & 6848.26 \\
VI & 17512.50 & 20 & 3502.40 \\
\hline
\end{tabular}

Because of alternative and traditional water intakes applied in the studied objects, a comparative simulation of the system operation costs was carried out. In objects I, II and IV, water was not taken from the pipeline network because of the possibility and justification of using other methods of water supply. In the remaining objects (III, V and VI) localised in areas with a compact housing development, connections to pipeline network were made. The calculation of simulation costs had to show whether the use of alternative water sources is more economic or not. As for electric power consumption, one can accept the principles qualifying the energy receivers to particular groups of electric energy charges (acc. to Taryfa..., 2007). In case of automatic irrigation system, the most favourable period for irrigation is night and early morning not only because of the plant requirements, but also because of economic reasons. Selection of an adequate group of electric energy charges, considering the time zones and the period of system operation, permits to make some savings. Based on the above data, the most justified is the acceptation of the C12 group of electric energy charges (acc. to Taryfa..., 2007).

Table 5 shows water demand and water discharge in particular objects. In case of objects I, III and VI, which include areas covered with ornamental plants, an additional irrigation by a drip-line was introduced.

An analysis of operation costs (Fig. 1) was also performed. These costs included not only the costs of water and electric energy, but also the costs connected with the seasonal operation of the system including the start-up, regulation of elec- 
Table 5. Water demand and water discharge

\begin{tabular}{|c|c|c|c|c|c|c|}
\hline \multirow{2}{*}{ Specification } & \multicolumn{6}{|c|}{ Objects } \\
\hline & I & II & III & IV & V & VI \\
\hline \multicolumn{7}{|c|}{ Water demand } \\
\hline Optimal dose, mm & 5 & 8 & 5 & 8 & 5 & 5 \\
\hline Gross dose, $\mathrm{mm}$ & 5.8 & 9.4 & 5.8 & 9.4 & 5.8 & 5.8 \\
\hline $\begin{array}{l}\text { Water volume in one cycle of irrigation } \\
\text { by sprinklers, } \mathrm{m}^{3}\end{array}$ & 59.5 & 74.2 & 10.0 & 74.2 & 44.0 & 5.0 \\
\hline $\begin{array}{l}\text { Water volume in one cycle of irrigation } \\
\text { by drip pipe line, } \mathrm{m}^{3}\end{array}$ & 29.5 & - & 2.0 & - & - & 1.0 \\
\hline \multicolumn{7}{|c|}{ Water discharge } \\
\hline Water discharge by sprinklers, $\mathrm{m}^{3} \cdot \mathrm{h}^{-1}$ & 84.0 & 85.9 & 16.8 & 139.4 & 27.2 & 9.6 \\
\hline Operation time, min. & 45 & 55 & 50 & 30 & 90 & 30 \\
\hline $\begin{array}{l}\text { Water discharge by drip pipeline (m), } \\
\mathrm{m}^{3} \cdot \mathrm{h}^{-1}\end{array}$ & 0.0066 & - & 0.0066 & - & - & 0.0066 \\
\hline Operation time, min. & 60 & - & 60 & - & - & 60 \\
\hline $\begin{array}{l}\text { Total water discharge by irrigation sys- } \\
\text { tem, } \mathrm{m}^{3}\end{array}$ & 90.0 & 78.0 & 12.0 & 75.0 & 45.0 & 6.0 \\
\hline
\end{tabular}

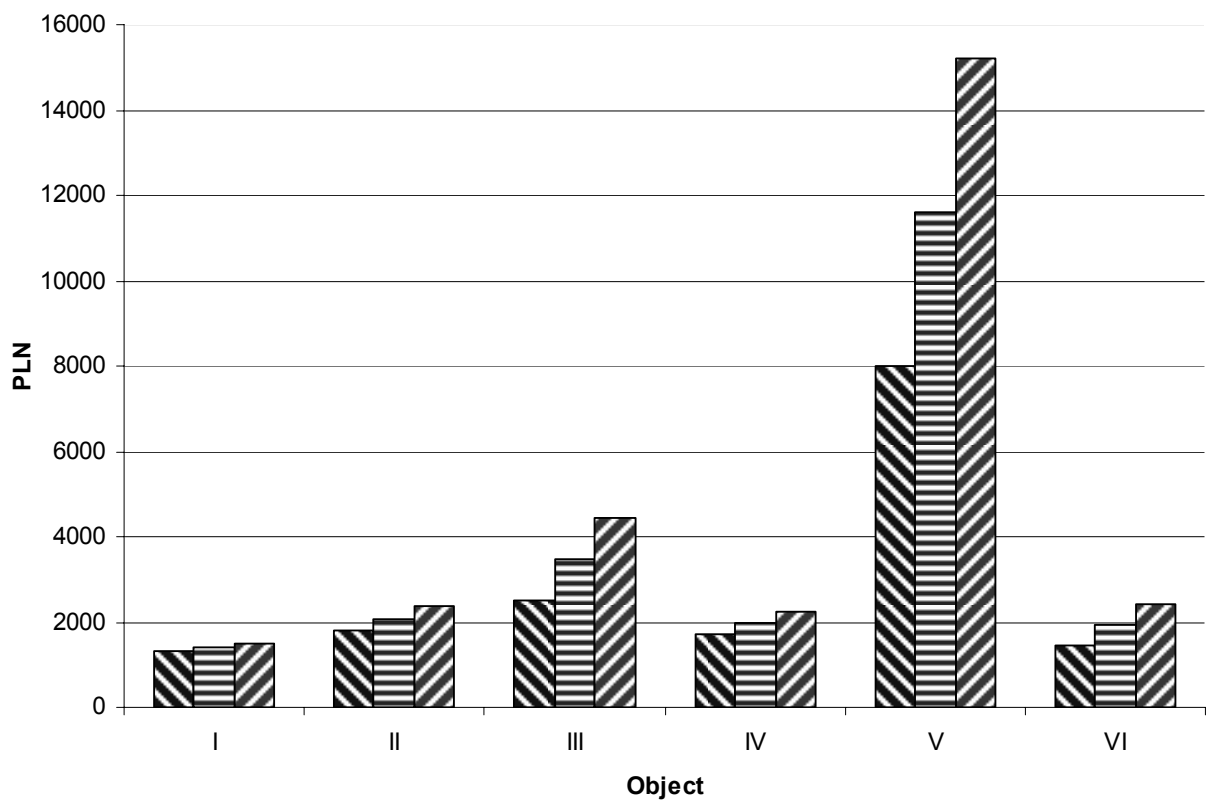

Wet year $\square$ Average year $\boldsymbol{\square}$ Dry year

Fig. 1. Total operation costs $K_{b}$ of irrigation systems in wet year, average year and dry year 
tric feeders, replacement or cleaning of filters, periodical surveys, current repairs and the system preparation for winter season.

The highest operation costs were noted for object V. The operation costs of the remaining objects, independent of atmospheric precipitations ranged between 1.5-4.0 thous. PLN. Such significant difference was caused by the fact that the area of the sports stadium is irrigated from the water-pipe network.

Table 6 contains the investment cost connected with the construction of an irrigation system per $1 \mathrm{~m}^{2}$. The lowest cost (below 7.00 PLN per $1 \mathrm{~m}^{2}$ ) was attained in the construction of the irrigation system in the athletic stadium. This was possible due to the existing underground infrastructure and adaptation of the existing technological inspection shaft. The highest cost of about 20.00 PLN per $1 \mathrm{~m}^{2}$ was calculated for the construction of the irrigation system in the central part of the town. Strongly developed infrastructure, comparatively small and separated, and the separation of vegetation areas irrigated by a drip-line explain these high outlays. The unit cost of the construction of irrigation systems on the remaining objects varied around $12.00 \mathrm{PLN} \cdot \mathrm{m}^{-2}$.

Table 6. Construction and operation costs $K_{b}\left(\right.$ in $\left.\mathrm{PLN} \cdot \mathrm{m}^{-2}\right)$ per square meter of the irrigated area

\begin{tabular}{l|r|r|r|rrrr}
\hline \multirow{2}{*}{\multicolumn{1}{c}{ Specification }} & \multicolumn{7}{c}{ Objects } \\
\cline { 2 - 7 } & \multicolumn{1}{c|}{ I } & \multicolumn{1}{c}{ II } & \multicolumn{1}{c}{ III } & \multicolumn{1}{c}{ IV } & \multicolumn{1}{c}{ V } & VI \\
\hline Construction cost of the irrigation system & 12.00 & 11.50 & 12.00 & 11.60 & 6.60 & 20.00 \\
Operation costs in a wet year & 0.13 & 0.13 & 1.47 & 0.22 & 1.05 & 1.68 \\
Operation costs in a average year & 0.14 & 0.15 & 2.04 & 0.25 & 1.53 & 2.23 \\
Operation costs in a dry year & 0.15 & 0.17 & 2.60 & 0.28 & 2.00 & 2.78 \\
\hline
\end{tabular}

Tables 6 and 7 present the operation costs per $1 \mathrm{~m}^{2}$ covered by irrigation system and the operation costs of sprinkle irrigation by $1 \mathrm{~m}^{3}$ of water, respectively. The highest costs of the irrigation system operation were recorded in objects supplied with water from the water-pipe network, i.e. in objects III, V and VI. There, the seasonal maximum operation cost in a dry year amounted from 2.00 to 2.78 PLN per $1 \mathrm{~m}^{2}$. In comparison, objects supplied with water from alternative sources generated a cost in the range from 0.15 to $0.28 \mathrm{PLN} \cdot \mathrm{m}^{-2}$. Also the cost of sprinkle irrigation with $1 \mathrm{~m}^{3}$ of water explicitly shows why the costs of object maintenance

Table 7. Operation costs $K_{b}$ (in PLN $\cdot \mathrm{m}^{-3}$ ) of the sprinkling of $1 \mathrm{~m}^{3}$ water

\begin{tabular}{l|c|c|c|c|c|c}
\hline \multirow{2}{*}{\multicolumn{1}{c|}{ Specification }} & \multicolumn{7}{c}{ Objects } \\
\cline { 2 - 7 } & I & II & III & IV & V & VI \\
\hline Water discharge in a wet year & 0.17 & 0.31 & 3.70 & 0.30 & 3.38 & 4.03 \\
Water discharge in an average year & 0.21 & 0.36 & 3.87 & 0.35 & 3.44 & 4.31 \\
Water discharge in a dry year & 0.29 & 0.46 & 4.20 & 0.46 & 3.56 & 4.87 \\
\hline
\end{tabular}


are lower. An analysis of a dry year showed that the operation costs of the objects III, V and VI amounted from 3.56 to $4.87 \mathrm{PLN} \cdot \mathrm{m}^{-3}$. In the same conditions, on the remaining objects the costs amounted from $0.29 \mathrm{PLN}$ per $\mathrm{m}^{3}$ of water in object I to $0.46 \mathrm{PLN}$ per $\mathrm{m}^{3}$ in the sports object IV and $0.46 \mathrm{PLN} \cdot \mathrm{m}^{-3}$ in object II.

Figures 2 and 3 show the unit costs of construction and operation of the irrigation systems in the annual cycle. The analysis was carried out in reference to two parameters: irrigated area $\left(\right.$ in $^{2}$ ) and the amount of utilised water $\left(\right.$ in $\left.\mathrm{m}^{3}\right)$. In the first case, the highest unit costs $E_{b}$ per $1 \mathrm{~m}^{2}$ of the irrigated area were noted in the urban green areas (objects III and VI) localised in a build-up area ranging in a wet year from $3.90 \mathrm{PLN} \cdot \mathrm{m}^{-2}$ in object III to $5.70 \mathrm{PLN} \cdot \mathrm{m}^{-2}$ in object $\mathrm{V}$. In the remaining objects, regardless of the year type, the unit costs did not exceed $3.00 \mathrm{PLN} \cdot \mathrm{m}^{-2}$.

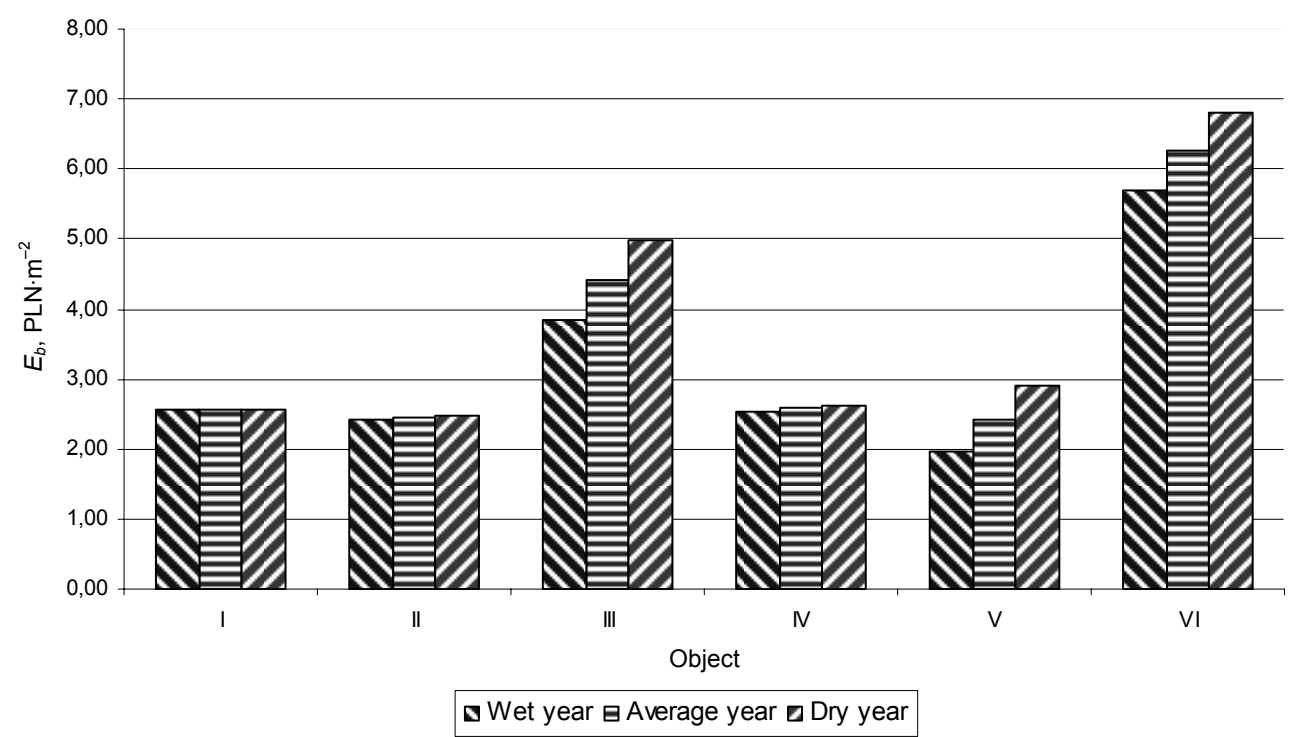

Fig. 2 Seasonal unit costs $E_{b}$ of irrigation systems in wet year, average year and dry year per $\mathrm{m}^{2}$ of irrigated area

The unit costs of water consumption $E_{b}$ in all objects were found to be higher in a dry year. The reason is obvious because a dry year requires more irrigations. However, the objects III and VI again showed the highest costs. The lowest costs, not exceeding 6.00 PLN $\cdot \mathrm{m}^{-3}$, were obtained in the objects I and IV. 


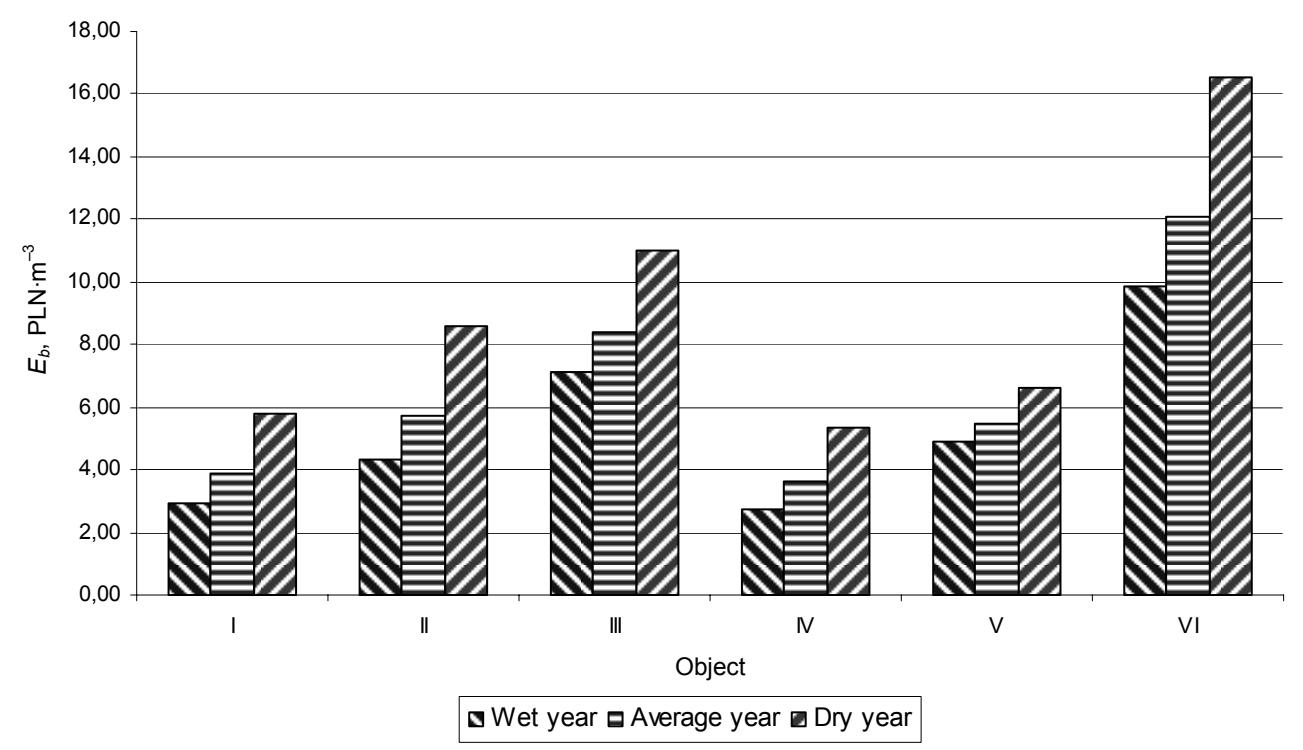

Fig. 3. Seasonal unit costs $E_{b}$ of irrigation systems in wet year, average year and dry year per $\mathrm{m}^{3}$ of sprinkling water

\section{DISCUSSION}

A problem to be considered is not whether it is justified to use irrigation systems, but rather what type of irrigation installations to select. In the present paper different methods of irrigation designed for different purposes were presented. The differences resulted not only from the specificity of a given object, but primarily from the available financial resources for both the installation and maintenance of the installed project. The lack of adequate financial means for such project results from the fact that local authorities responsible for investments in their regions do not devote enough consideration to the price of the realized project whose costs keep increasing every year. According to SzCZEPANOWSKA (2001), the increasing value of trees in urban areas contributed to the fact that the value of trees was acknowledged as an element of the fixed assets of the town. Newly established green areas in a town are supported by municipal funds, but there are no or little funds foreseen for the cultivation of the already existing green areas. The specificity of green belts cultivation requires that they have to be cared by specialized companies which is costly and often exceeds the cost of new green belts. Lacking financial means for the continued cultivation purposes frequently leads to a devastation of the existing irrigation systems. However, an absence of an irrigation system at the very beginning of a green area project undermines the project before its realization. The adaptation of a terrain to the installation of an irrigation system is much more 
expensive than when developed together with the realization of the planned green area. A rational project has to be designed in such a way that the costs of accompanying irrigation system are as low as possible and as simple as possible. The structure of costs presented in particular objects indicates that over one half of the costs is consumed by materials and almost the other half must be spent for labour. The remaining costs cover the equipment. However, it does not mean that the equipment's cost is marginal, because if it were, the labour cost would exceed the costs of the whole investment. An adequately developed machine and instrumentation equipment reduces significantly the labour costs and accelerate the construction of the irrigation system. Besides, one should also take into account the method of an adequate protection of the irrigation system elements. More and more frequently the establishment of a green area is also accompanied by a monitoring system.

\section{CONCLUSIONS}

1. Comparison of long-term atmospheric precipitations with the curve of plant growth shows that installation of an irrigation system is justified if adequate water amount in the vegetation season (April-September, i.e. in the period of an intensive growth and tilling of plants) is essential. Inadequate amount of water in that period causes plant wilting and even their death and some problems with regeneration in the further part of the vegetation period. The use of an irrigation system in sports and recreation areas is justified not only in view of an extensive utilization, but also because of aesthetic values of given areas.

2. Calculated per square meter of the irrigated area, the cost of the establishment of an automatic irrigation system varies from about 7.00 PLN up to even 20.00 PLN. Such a wide range is caused not only by the relation: „the greater the area, the smaller are the unit costs", but also because of the complication of the chosen system.

3. Cost structure of the establishment of an irrigation system indicates that over one half of the costs is connected with the costs of materials. Labour consumes almost the second half of the costs, while the remaining costs cover the instrumentation.

4. Analysis of unit costs $\left(E_{b}\right)$ demonstrate that it is worth investing in alternative water sources like deep wells and water intakes from surface reservoirs. Although they are more expensive when constructed from the base (about 30 thous. PLN), in comparison with the pipeline network (about 2 thous. PLN), they showed to be significantly cheaper in practical operation. A comparison of the operation costs per $1 \mathrm{~m}^{2}$ indicated that objects provided with alternative water sources are more than tenfold cheaper mainly because of the water price. 
5. It was shown that the drip pipeline in objects I, III and VI, makes a perfect supplementation of an irrigation system emerging from the ground because it irrigates plant surfaces which are not accessible for the sprinkling water stream.

\section{REFERENCES}

1. BARTosiewicz A., 1977. Urządzanie terenów zieleni. (Arrangement of green areas). Warszawa, PWSiP.

2. DRUPKA S., 1976. Techniczna i rolnicza eksploatacja deszczowni. (Technical and agricultural exploitation of irrigation machines). Warszawa, PWRiL.

3. PrzybyŁa Cz., KozaczyK P., 2004. Problemy eksploatacji deszczowni w warunkach gospodarki rynkowej. (Problems with the exploitation of sprinkling machines in market economy). Woda Środowisko Obszary Wiejskie t. 4 z. 2a (11): 25-38.

4. SzCZEPANOwSKA H.B., 2001. Drzewa w mieście. (Trees in a city). Warszawa, Hortpress Sp. z.o.o.

5. Taryfa dla energii elektrycznej (Electricity tariff), 2007. Gdańsk, Koncern Energet. Energa SA.

\section{STRESZCZENIE}

\section{Koszty budowy i eksploatacji systemów nawadniających na terenach rekreacyjnych i sportowych}

Słowa kluczowe: linia kroplująca, system nawadniajacy, ujęcie wody, zraszacz

$\mathrm{W}$ pracy podjęto problematykę kosztów inwestycji, związanych z systemami nawadniającymi na obiektach rekreacyjnych i sportowych, oraz kosztów utrzymania i eksploatacji tych urządzeń. Wykorzystano w tym celu zebrane materiały źródłowe dla sześciu obiektów, realizowanych w latach 2006-2007 w powiecie konińskim. Szczegółową analizą objęto źródła wody do nawodnień, koszty ujęć oraz koszty założenia systemu nawadniającego w zróżnicowanych warunkach eksploatacji. Ponadto analizą kosztów objęto utrzymanie i eksploatację poszczególnych obiektów. Efektem tych obliczeń są jednostkowe koszty inwestycji $E_{b}$ oraz jednostkowe koszty eksploatacji, przypadające na $\mathrm{m}^{2}$ nawadnianej powierzchni oraz koszty rozdeszczowania $1 \mathrm{~m}^{3}$ wody.

Received 09.03.2010

Reviewers:

Dr Józef Lipiński

Prof. Henryk Manteuffel-Schoege 